\title{
BEBERAPA FAKTOR YANG MEMPENGARUHI PERMINTAAN DAGING AYAM BROILER PADA RUMAH TANGGA DI KECAMATAN IDI RAYEUK KABUPATEN ACEH TIMUR
}

\author{
Ahmad Ridha \\ Dosen Fakultas Ekonomi Universitas Samudra \\ Email : achmad.ridha@gmail.com
}

\begin{abstract}
ABSTRAK
Penelitian ini bertujuan untuk mengetahui beberapa faktor yang mempengaruhi permintaan daging ayam broiler di Kecamatan Idi Rayeuk Kabupaten Aceh Timur. Metode dasar yang digunakan adalah deskriptif analisis dan kuantitatif. Berdasarkan hasil penelitian dengan menggunakan analisis regresi linier berganda diperoleh nilai koefesien determinasi $\left(\mathrm{R}^{2}\right)$ sebesar 0.7234 menunjukkan bahwa 72,34 persen variasi variabel dependen (permintaan daging ayam broiler di Kecamatan Idi Rayeuk) mampu dijelaskan oleh variabel independen yang dimasukkan ke dalam model (pendapatan keluarga, harga daging ayam broiler, harga daging ayam kampung, harga ikan, harga telur, jumlah tanggungan keluarga, dan pendidikan Ibu rumah tangga, sedangkan sisanya sebesar 27,66 persen dipengaruhi oleh faktor lain yang tidak dimasukkan dalam model. Hasil uji $\mathrm{F}$ diperoleh nilai $\mathrm{F}_{\text {hitung }}$ sebesar 21.180 nilai tersebut menunjukkan bahwa nilai $\mathrm{F}_{\text {hitung }}>\mathrm{F}_{\text {Tabel }}$ pada tingkat kepercayaan 95 persen. selanjutnya hasil uji t menunjukkan 4 variabel penelitian berpengaruh nyata terhadap permintaan daging ayam broiler di Kecamatan Idi Rayeuk dengan nilai $\mathrm{t}_{\text {hitung }}$ untuk masing-masing variabel lebih besar dari $\mathrm{t}_{\text {tabel}}$, antara lain pendapatan keluarga, harga ayam daging broiler, harga ikan dan jumlah tanggungan keluarga. Sedangkan harga telur, harga ayam kampung dan tingkat pendidikan ibu rumah tangga tidak berpengaruh nyata terhadap permintaan daging ayam broiler di Kecamatan Idi Rayeuk.
\end{abstract}

Kata kunci : Permintaan, Ayam Broiler, Rumah Tangga

\section{PENDAHULUAN}

Meningkatnya kesadaran masyarakat terhadap nilai gizi telah meningkatkan permintaan terhadap daging ayam secara umum dan khususnya daging ayam broiler di Indonesia. Daging ayam broiler merupakan salah satu sumber bahan pangan hewani yang mengandung gizi cukup tinggi berupa protein dan energi. Berdasarkan data dari Kementrian RI tahun 2016 daging ayam lebih banyak dikonsumsi dibandingkan dengan daging sapi karena harga daging ayam lebih terjangkau dibandingkan daging sapi. Sejak tahun 2010, Indonesia sudah 
dapat melaksanakan swasembada daging ayam, dengan kata lain kebutuhan daging ayam dapat dicukupi dari produksi dalam negeri.

Daging ayam merupakan sumber bahan pangan protein yang sangat penting untuk meningkatkan kualitas sumber daya manusia Indonesia. Perkembangan populasi dan hasil produksinya merupakan gambaran tingkat ketersediaan sumber bahan protein nasional. Tingkat konsumsi yang akan menentukan kualitas sumber daya manusia dipengaruhi oleh tingkat ketersediaan daging dan produksi ternak lainnya dan tingkat pendapatan rumahtangga (purchasing power). Faktor tingkat pendapatanlah yang akan menentukan apakah rumahtangga/individu akan lebih banyak mengkonsumsi sumber karbohidrat atau protein, yang akan berpengaruh pada tingkat konsumsi berkualitas dan sesuai dengan persyaratan gizi.

Berdasarkan data Survei Sosial Ekonomi Nasional (SUSENAS) tahun 2011- 2014 secara agregat perkembangan konsumsi protein hewani khususnya dari daging ayam broiler per kapita masyarakat Indonesia cenderung meningkat sebesar 2,27\% per tahun. Pada tahun 2014 konsumsi daging ayam broiler nasional rata-rata sebesar $3,75 \mathrm{Kg} / \mathrm{Kapita} /$ Tahun. Beberapa faktor yang dapat mempengaruhi peningkatan konsumsi daging ayam nasional seperti adanya peningkatan pertumbuhan jumlah penduduk dan tingkat pendapatan masyarakat yang cenderung meningkat.

Data permintaan daging ayam broiler di Kabupaten Aceh Timur tiap tahunnya relatif meningkat. Pada tahun 2015 permintaan terhadap ayam petelur mencapai 101.174 ekor dan ayam broiler mencapai 350.203 ekor. Dibandingkan dengan tahun yang sama pada tahun 2014, terjadi peningkatan untuk ayam broiler yang relatif tinggi mencapai 21 persen dari tahun sebelumnya (BPS, Kab. Aceh Timur, 2016). Sedangkan jika dilihat permintaan ayam daging ayam broiler di Kecamatan Idi Rayeuk sebagai pusat ibukota Kabupaten Aceh Timur relatif tinggi dibandingkan dengan wilayah kecamatan yang lain dalam Kabupaten Aceh Timur. Beberapa faktor yang diduga mempengaruhi permintaan terhadap ayam broiler di Kecamatan Idi Rayeuk antara lain, harga ikan, harga daging ayam broiler, pendapatan masyarakat, dan juga adanya faktor sosial seperti pendidikan, dan kesadaran akan gizi, serta peningkatan jumlah penduduk.

Adapun tujuan dari penelitian ini adalah untuk mengetahui faktor-faktor yang mempengaruhi permintaan daging ayam di tingkat rumah tangga di Kecamatan Idi Rayeuk Kabupaten Aceh Timur.

\section{TINJAUAN PUSTAKA}

\section{Permintaan}

Teori permintaan menerangkan tentang ciri hubungan di antara jumlah permintaan dan harga. Hukum permintaan pada hakekatnya merupakan suatu 
hipotesa yang menyatakan bahwa semakin rendah harga suatu barang, maka semakin banyak permintaan terhadap barang tersebut. Sebaliknya semakin tinggi harga barang tersebut, maka semakin sedikit permintaan terhadap barang tersebut (Sukirno, 2006). Lebih lanjut Lipsey et al., (1995) mengatakan bahwa permintaan adalah hubungan menyeluruh antara kuantitas komoditi tertentu yang akan dibeli oleh konsumen selama periode waktu tertentu dengan harga komoditi tertentu. Menurut Salvator (2006), permintaan adalah jumlah suatu komoditi yang bersedia dibeli individu selama periode waktu tertentu merupakan fungsi dari atau tergantung pada komoditi tersebut, pendapatan nominal individu, harga komoditi lain, jumlah penduduk dan cita rasa individu.

Permintaan adalah keinginaan konsumen membeli suatu barang pada berbagai tingkat harga selama periode waktu tertentu Besarnya permintaan suatu barang atau produk ditentukan oleh banyak faktor diantaranya : harga barang itu sendiri, harga barang lain, tingkat pendapatan perkapita, selera atau kebiasaan, jumlah penduduk, perkiraan harga di masa depan, distribusi pendapatan, dan usaha-usaha produsen meningkatkan pendapatan. (Rahardja dan Manurung 2006).

Harga suatu barang dan jumlah barang yang diperjual belikan ditentukan oleh permintaan dan penawaran dari barang tersebut. Oleh karena itu, untuk menganalisis mekanisme penetuan harga dan jumlah barang yang diperjualbelikan maka diperlukan analisis permintaan dan penawaran atas suatu barang tertentu di pasar. Keadaan suatu pasar dikatakan seimbang apabila jumlah yang ditawarkan sama dengan jumlah barang yang diminta konsumen pada tingkat harga tersebut (Sukirno, 2006).

Harga barang lainnya terdiri dari harga barang subtitusi dan komplementer. Barang substitusi adalah barang-barang yang dapat saling menggantikan satu sama lain dalam konsumsi. Barang komplementer adalah barang-barang yang digunakan bersama dalam pengertian bahwa para individu akan menambah pemakaian atas kedua barang itu secara serempak. Barang X dan Y disebut sebagai barang komplemen jika kenaikan harga barang X menyebabkan harga barang Y lebih sedikit diminta. Keduanya merupakan barang substitusi jika kenaikan harga barang $\mathrm{X}$ menyebabkan harga barang $\mathrm{Y}$ lebih banyak diminta (Nicholson, 1999).

Apabila pendapatan naik maka dapat diperkirakan bahwa orang akan membeli lebih banyak beberapa komoditi, walaupun harga komoditi-komoditi itu tetap sama. harga berapapun yang diambil, jumlah komoditi yang diminta akan lebih banyak daripada yang diminta sebelumnya pada tingkat harga yang sama. pertumbuhan jumlah penduduk belum menciptakan permintaan baru. Penduduk yang bertambah ini harus mempunyai daya beli sebelum permintaan berubah. Apabila hal ini terjadi maka permintaan untuk semua komoditi yang dibeli oleh penghasil pendapatan baru akan meningkat sehingga kenaikan jumlah penduduk akan menggeser kurva permintaa untuk komoditi kearah kanan, yang menunjukkan bahwa akan lebih banyak komoditi yang dibeli pada setiap tingkat harga (Lipsey et al, 1995). 


\section{METODE PENELITIAN}

\section{Lokasi Penelitian}

Penelitian dilaksanakan di Kecamatan Idi Rayeuk, dengan memilih 5 desa sebagai sampel, yaitu: Desa Tanoh Anoe, Desa Gp. Blang, Desa Keude Aceh, Desa Gp. Jalan, dan Desa Gp. Jawa. Lokasi penelitian ditentukan secara sengaja (purposive) dengan pertimbangan Kecamatan Idi Rayeuk merupakan salah satu wilayah dengan permintaan konsumsi ayam broiler relatif tinggi dibandingkan dengan daerah lainnya dalam Kabupaten Aceh Timur (BPS Aceh Timur, 2016). Responden sampel pada tingkat desa dipilih secara acak (simple random sampling) untuk menghindari pemilihan sampel secara subjektif. Jumlah sampel ditentukan secara sengaja yakni 12 responden pada tiap desa sehingga jumlah responden keseluruhan berjumlah 60 responden.

Jenis data yang dikumpulkan adalah data primer dan data sekunder. Data primer langsung dikumpulkan daru rumah tangga sebagai responden sesuai daftar pertanyaan yang telah disiapkan. Sedangkan data sekunder dikumpulkan dari instansi terkait.

\section{Analisis Data}

Metode dasar yang digunakan adalah metode deskriptif analisis dan metode kuantitatif untuk menganalisis beberapa faktor yang mempengaruhi permintaan daging ayam broiler pada rumah tangga di Kecamatan Idi Rayeuk. Pengolahan data dilakukan dengan menggunakan tabulasi. Sedangkan untuk menganalisis faktor-faktor yang mempengaruhi konsumsi daging ayam menggunakan analisis statistik dengan menggunakan software SPSS Statistics v21.0 untuk mempermudah perhitungan dan analisis. Metode yang digunakan adalah metode regresi linier berganda dengan persamaan regresi sebagai berikut:

$$
\begin{aligned}
& \mathrm{Y}=\mathrm{a}+\mathrm{b}_{1} \mathrm{X}_{1}+\mathrm{b}_{2} \mathrm{X}_{2}+\mathrm{b}_{3} \mathrm{X}_{3}+\mathrm{b}_{4} \mathrm{X}_{4}+\mathrm{b}_{5} \mathrm{X}_{5}+\mathrm{b}_{6} \mathrm{X}_{6}+\mathrm{b}_{7} \mathrm{X}_{7}+\mathrm{e} \\
& \text { Keterangan : } \\
& \mathrm{Y}=\text { Permintaan daging ayam broiler } \\
& \mathrm{a}=\text { Konstanta } \\
& \mathrm{b}_{1-7}=\text { Koefesien regresi } \\
& \mathrm{X}_{1}=\text { Pendapatan keluarga } \\
& \mathrm{X}_{2}=\text { Harga ayam kampung } \\
& \mathrm{X}_{3}=\text { Harga daging ayam broiler } \\
& \mathrm{X}_{4}=\text { Harga ikan } \\
& \mathrm{X}_{5}=\text { Harga telur } \\
& \mathrm{X}_{6}=\text { Jumlah tanggungan keluarga } \\
& \mathrm{X}_{7}=\text { Tingkat pendidikan ibu rumah tangga } \\
& \mathrm{e}=\text { Residual }
\end{aligned}
$$




\section{HASIL PENELITIAN DAN PEMBAHASAN}

\section{Karakteristik Responden}

Berdasarkan hasil survei terhadap responden diperoleh distribusi jumlah rumah tangga yang menkonsumsi daging ayam broiler untuk satu bulan yaitu: 1 $2,9 \mathrm{~kg}$ sebanyak 17 responden (28,3\%), konsumsi $3-4,9 \mathrm{~kg}$ sebanyak 15 responden $(25,0 \%)$ dan $>5 \mathrm{~kg}$ sebanyak 28 responden $(46,6 \%)$. Hasil penelitian menunjukkan rata-rata intensitas pembelian ayam broiler oleh responden mencapai 1 sampai 3 kali sebulan.

Sedangkan jika dilihat dari tingkat pendidikan ibu rumah tangga rata-rata memiliki pendidikan SMA sebanyak 42 responden (70\%), sedangkan sisanya pendidikan SD sebanyak 7 responden $(11,6 \%)$ dan pendidikan SMP sebanyak 11 responden $(18,3 \%)$.

Sedangkan jumlah tanggungan keluarga rata-rata responden yaitu responden dengan jumlah tanggungan $>4$ orang sebanyak 31 responden $(51,6 \%)$, jumlah tanggungan 3 orang sebanyak 19 responden $(31,7 \%)$, sedangkan jumlah responden $<2$ orang sebanyak 10 orang $(16,7 \%)$. Hasil penelitian di lokasi pasar Idi Rayeuk menunjukkan rata-rata harga ayam broiler mencapai Rp. 22.000, $26.000 / \mathrm{Kg}$.

Jika dilihat dari alasan responden mengkonsumsi ayam broiler menunjukkan bahwa pilihan harga yang murah merupakan alasan utama, selanjutnya rasa yang enak merupakan pilihan kedua yang banyak mempengaruhi konsumsi ayam broiler. Jika dibandingkan harga ayam broiler dengan harga ikan di kecamatan Idi Rayeuk relatif sama, artinya beberapa harga ikan yang umum di beli di pasar Idi Rayeuk seperti ikan Tongkol, ikan Bandeng justru harga ikan tersebut relatif bekisar antara Rp. 20.000,- s/d Rp. 30.000,-/ kg. Hal ini menunjukkan harga ikan dapat menjadi substitusi yang sangat kuat terhadap daging ayam broiler, karena harganya yang relatif hampir mendekati sama.

\section{Faktor-Faktor yang Mempengaruhi Permintaan Daging Ayam Broiler}

Dari hasil pengolahan dengan menggunakan program SPPS v.20.0 diperoleh persamaan regresi linier berganda yaitu : $\mathrm{Y}=2.837+0.197 \mathrm{X}_{1}+1.608$ $\mathrm{X}_{2}-0.507 \mathrm{X}_{3}+0.641 \mathrm{X}_{4}+0.093 \mathrm{X}_{5}+0.802 \mathrm{X}_{6}+0.192 \mathrm{X}_{7}$

dari hasil persamaan regresi menunjukkan bahwa nilai konstanta sebesar 2.837 . Nilai tersebut menunjukkan bahwa permintaan daging ayam broiler akan bernilai 2.837 apabila faktor lain sama dengan nol. Dengan kata lain permintaan daging ayam broiler berada pada tingkat 4.927 jika tidak ada aktifitas konsumsi jenis lauk lain.

Koefisien regresi variabel pendapatan keluarga $\left(\mathrm{X}_{1}\right)$ bernilai positif sebesar 0.197. Tanda positif ini menunjukan pengaruh yang searah antara pendapatan keluarga dengan permintaan daging ayam broiler di Kecamatan Idi 
Rayeuk. Artinya jika pendapatan meningkat, maka akan ada peningkatan permintaan daging ayam broiler sebesar 0.197 persen.

Selanjutnya koefesien regresi untuk harga ayam kampung $\left(\mathrm{X}_{2}\right)$ sebesar 1.608. Tanda positif menunjukkan pengaruh yang searah antara harga ayam kampung dengan permintaan daging ayam broiler. Artinya apabila harga ayam kampung meningkat maka akan meningkatkan permintaan daging ayam broiler sebesar 1.608 persen. Hal ini menunjukkan bahwa daging ayam broiler dapat menjadi barang substitusi bagi ayam kampung, karena saat ini harga ayam kampung di Kecamatan Idi Rayeuk bisa mencapai 2 kali lipat dari harga ayam broiler.

Selanjutnya koefesien regresi untuk harga daging ayam broiler $\left(\mathrm{X}_{3}\right)$ sebesar - 0,507. Bertanda negatif, menunjukkan bahwa pengaruh yang berlawanan arah. Artinya jika harga daging ayam broiler meningkat sebesar satu satuan, maka akan menurunkan permintaan daging ayam broiler sebesar 0,507 persen.

Selanjutnya koefesien regresi untuk harga ikan $\left(\mathrm{X}_{4}\right)$ sebesar 0,641 bertanda positif. Hal ini menunjukkan pengaruh yang searah antara harga ikan dan permintaan daging ayam broiler di Kecamatan Idi Rayeuk. Artinya jika harga ikan meningkat sebesar satu satuan, maka akan meningkatkan permintaan daging ayam broiler sebesar 0,641 persen. hal ini menunjukkan bahwa ikan dan daging ayam broiler dapat menjadi barang subtitusi di Kecamatan Idi Rayeuk. Hal ini disebabkan harga beberapa jenis ikan di Pasar Idi Rayeuk tidak terlalu jauh berbeda dengan harga daging ayam.

Harga telur $\left(\mathrm{X}_{5}\right)$ memiliki nilai koefesien regresi sebesar 0.093 dan bernilai positif. Hal ini menunjukkan bahwa meningkatnya harga telur ayam seebsar satu satuan maka akan meningkatkan permintaan daging ayam broiler di Kecamatan Idi Rayeuk sebesar 0.093 persen.

Selanjutnya nilai koefesien variabel jumlah tanggungan keluarga $\left(\mathrm{X}_{6}\right)$ sebesar 0.802 dan bernilai positif. Menunjukkan bahwa meningkatnya jumlah tanggungan keluarga sebesar satu satuan maka akan meningkatkan permintaan daging ayam broiler sebesar 0.802 persen. sedangkan variabel pendidikan ibu rumah tangga $\left(\mathrm{X}_{7}\right)$ memiliki nilai koefesien regresi sebesar - 0.192 dan bernilai negatif.

\section{Uji Koefisien Determinasi $\left(\mathbf{R}^{2}\right)$}

Koefisien determinasi menunjukkan seberapa besar variasi peubah variabel tidak bebas yang dapat dijelaskan oleh variasi peubah variabel bebas. Berdasarkan hasil analisis regresi linier berganda diperoleh nilai koefisien determinasi $\left(\mathrm{R}^{2}\right)$ sebesar 0.7234 menunjukkan bahwa 72,34 persen variasi variabel dependen (permintaan daging ayam broiler di Kecamatan Idi Rayeuk) mampu dijelaskan oleh variabel independen yang dimasukkan ke dalam model 
(pendapatan keluarga, harga daging ayam broiler, harga daging ayam buras, harga ikan, harga telur, jumlah tanggungan keluarga, dan pendidikan Ibu rumah tangga, sedangkan sisanya sebesar 27,66 persen dipengaruhi oleh faktor lain yang tidak dimasukkan dalam model.

\section{Uji F (Uji Simultan)}

Berdasarkan hasil analisis, nilai $\mathrm{F}_{\text {hitung }}$ adalah sebesar 21.180 nilai tersebut menunjukkan bahwa nilai $\mathrm{F}_{\text {hitung }}>\mathrm{F}_{\text {Tabel }}$ pada tingkat kepercayaan 95 persen. dengan nilai signifikasi sebesar 0.000 lebih kecil dari 0.05 . Hal ini berarti permintaan daging ayam broiler di Kecamatan Idi Rayeuk dipengaruhi secara simultan oleh variabel independen yang ada dalam model. Dengan demikian dugaan bahwa permintaan daging ayam dipengaruhi oleh jumlah pendapatan keluarga, harga daging ayam broiler, harga daging ayam buras, harga ikan, harga telur, jumlah tanggungan keluarga, dan pendidikan Ibu rumah tangga dapat diterima.

\section{Uji t}

Berdasarkan hasil uji signifikasi individual (uji t), diketahui bahwa terdapat 4 variabel independen yang berpengaruh signifikan terhadap permintaan konsumsi daging ayam broiler, antara lain, pendapatan keluarga, harga daging ayam broiler, harga ikan, dan jumlah tanggungan keluarga. Penjelasan secara rinci mengenai faktor-faktor yang berpengaruh nyata terhadap permintaan daging ayam broiler sebagai berikut :

a. Variabel pendapatan keluarga $\left(\mathrm{X}_{1}\right)$ mempunyai nilai $\mathrm{t}_{\text {hitung }}$ sebesar 2.309 lebih besar dari $t_{\text {tabel}}$, sehingga dapat disimpulkan bahwa variabel pendapatan keluarga berpengaruh nyata terhadap permintaan daging ayam broiler di Kecamatan Idi Rayeuk pada tingkat kepercayaan 95 persen.

b. Variabel harga ayam kampung $\left(\mathrm{X}_{2}\right)$ mempunyai nilai t hitung sebesar 1.725 lebih kecil dari $\mathrm{t}_{\text {tabel}}$, sehingga dapat disimpulkan bahwa variabel harga ayam kampung tidak berpengaruh nyata terhadap permintaan daging ayam broiler pada tingkat kepercayaan 95 persen.

c. Variabel harga daging ayam broiler $\left(\mathrm{X}_{3}\right)$ mempunyai nilai $\mathrm{t}_{\text {hitung }}$ sebesar 8.306 lebih besar dari $t_{\text {tabel}}$, sehingga dapat dinyatakan variabel harga daging ayam broiler berpengaruh nyata terhadap permintaan daging ayam broiler.

d. Variabel harga ikan $\left(\mathrm{X}_{4}\right)$ mempunyai nilai thitung sebesar 4.631 lebih besar dari $t_{\text {tabel. }}$ Artinya harga ikan berpengaruh nyata terhadap permintaan daging ayam broiler.

e. Variabel harga telur $\left(\mathrm{X}_{5}\right)$ mempunyai nilai $\mathrm{t}_{\text {hitung }}$ sebesar 0.955 lebih kecil dari $\mathrm{t}_{\text {tabel. }}$ Artinya harga telur tidak mempunyai pengaruh nyata terhadap permintaan daging ayam broiler di Kecamatan Idi Rayeuk. 
f. Variabel jumlah tanggungan keluarga $\left(\mathrm{X}_{6}\right)$ mempunyai nilai $\mathrm{t}_{\text {hitung }}$ sebesar 2.692 lebih besar dari $t_{\text {tabel }}$, artinya jumlah tanggungan keluarga berpengaruh nyata terhadap permintaan daging ayam broiler di Kecamatan Idi Rayeuk.

g. Variabel tingkat pendidikan ibu rumah tangga $\left(\mathrm{X}_{7}\right)$ mempunyai nilai $\mathrm{t}_{\text {hitung }}$ sebesar 0.482 lebih kecil dari $\mathrm{t}_{\text {tabel. }}$. Artinya tingkat pendidikan ibu rumah tangga tidak berpengaruh nyata terhadap permintaan daging ayam broiler di Kecamatan Idi Rayeuk.

\section{KESIMPULAN}

Berdasarkan hasil penelitian tentang beberapa faktor yang mempengaruhi permintaan daging ayam broiler di Kecamatan Idi Rayeuk dapat diambil kesimpulan sebagai berikut:

1. Faktor-Faktor yang mempengaruhi permintaan daging ayam broiler di Kecamatan Idi Rayeuk adalah pendapatan keluarga, harga daging ayam broiler, harga ikan, dan jumlah anggota keluarga. Sedangkan harga ayam kampung, tingkat pendidikan ibu rumah tangga tidak berpengaruh nyata terhadap permintaan daging ayam broiler.

2. Analisis determinasi $\left(\mathrm{R}^{2}\right)$ sebesar 0.7234 menunjukkan bahwa 72,34 persen variasi variabel dependen (permintaan daging ayam broiler di Kecamatan Idi Rayeuk) mampu dijelaskan oleh variabel independen yang dimasukkan ke dalam model (pendapatan keluarga, harga daging ayam broiler, harga ayam kampung, harga ikan, harga telur, jumlah tanggungan keluarga, dan pendidikan Ibu rumah tangga, sedangkan sisanya sebesar 27,66 persen dipengaruhi oleh faktor lain yang tidak dimasukkan dalam model.

\section{SARAN}

Diperlukan upaya dari berbagai pihak terutama Pemerintah Daerah untuk melakukan sosialisasi mengenai nilai gizi untuk meningkatkan konsumsi protein hewani di dalam masyarakat di Kecamatan Idi Rayeuk.

\section{DAFTAR PUSTAKA}

Badan Pusat Statistik, 2016. Aceh Timur Dalam Angka 2015. BPS Kabupaten Aceh Timur.

Badan Pusat Statistik, 2016. Kecamatan Idi Rayeuk Dalam Angka. BPS Kabupaten Aceh Timur.

Kementrian Pertanian, 2015. Outlok Komoditas Pertanian Subsektor Peternakan. Jakarta: Pusat Data dan Sistem Informasi Pertanian.

Lipsey, G. R., P. O. Steiner and P. D. Purvis. 1995. Pengantar Mikroekonomi. Edisi Kesepuluh. Binarupa Aksara, Jakarta.

Nicholson, Walter. 1999. Mikro Ekonomi Intermediates dan Aplikasinya. Edisi Kedelapan. Jakarta: Erlangga. 
Rahardja P, Manurung. 2006. Teori Ekonomi Mikro. Edisi Ke-3. Jakarta: Penerbit Fakultas Ekonomi Universitas Indonesia.

Salvatore, Dominick, 2006. Mikroekonomi. Edisi Empat. McGraw-Hill, Inc. New York.

Sukirno, Sadono, 2006, Pengantar Teori Mikro Ekonomi, Edisi Ketiga, Jakarta: PT. Raja Grafindo Perkasa. 